\title{
Endocannabinoid-Independent Retrograde Signaling at Inhibitory Synapses in Layer 2/3 of Neocortex: Involvement of Vesicular Glutamate Transporter 3
}

\author{
Tibor Harkany, ${ }^{1 \star}$ Carl Holmgren, ${ }^{2 \star}$ Wolfgang Härtig, ${ }^{3}$ Tayyaba Qureshi, ${ }^{4}$ Farrukh A. Chaudhry, ${ }^{4}$ Jon Storm-Mathisen, ${ }^{4}$ \\ Marton B. Dobszay, ${ }^{2}$ Paul Berghuis, ${ }^{1}$ Gunnar Schulte, ${ }^{1}$ Kyle M. Sousa, ${ }^{1}$ Robert T. Fremeau Jr, ${ }^{5}$ Robert H. Edwards, ${ }^{5}$ \\ Ken Mackie, ${ }^{6}$ Patrik Ernfors, ${ }^{1}$ and Yuri Zilberter ${ }^{2}$ \\ ${ }^{1}$ Unit of Molecular Neurobiology, Department of Medical Biochemistry and Biophysics, and ${ }^{2}$ Department of Neuroscience, Karolinska Institutet, S-17177 \\ Stockholm, Sweden, ${ }^{3}$ Department of Neurochemistry, Paul Flechsig Institute for Brain Research, University of Leipzig, D-04109 Leipzig, Germany, \\ ${ }^{4}$ Department of Anatomy, Institute of Basic Medical Sciences, University of Oslo, N-0317 Oslo, Norway, ${ }^{5}$ Departments of Neurology and Physiology, \\ University of California San Francisco School of Medicine, San Francisco, California 94143, and ${ }^{6}$ Departments of Anesthesiology, and Physiology and \\ Biophysics, University of Washington, Seattle, Washington 98195
}

Recent studies implicate dendritic endocannabinoid release from subsynaptic dendrites and subsequent inhibition of neurotransmitter release from nerve terminals as a means of retrograde signaling in multiple brain regions. Here we show that type 1 cannabinoid receptor-mediated endocannabinoid signaling is not involved in the retrograde control of synaptic efficacy at inhibitory synapses between fast-spiking interneurons and pyramidal cells in layer $2 / 3$ of the neocortex.

Vesicular neurotransmitter transporters, such as vesicular glutamate transporters (VGLUTs) 1 and 2, are localized to presynaptic terminals and accumulate neurotransmitters into synaptic vesicles. A third subtype of VGLUTs (VGLUT3) was recently identified and found localized to dendrites of various cell types. We demonstrate, using multiple immunofluorescence labeling and confocal laserscanning microscopy, that VGLUT3-like immunoreactivity is present in dendrites of layer 2/3 pyramidal neurons in the rat neocortex. Electron microscopy analysis confirmed that VGLUT3-like labeling is localized to vesicular structures, which show a tendency to accumulate in close proximity to postsynaptic specializations in dendritic shafts of pyramidal cells. Dual whole-cell recordings revealed that retrograde signaling between fast-spiking interneurons and pyramidal cells was enhanced under conditions of maximal efficacy of VGLUT3-mediated glutamate uptake, whereas it was reduced when glutamate uptake was inhibited by incrementing concentrations of the nonselective VGLUT inhibitor Evans blue (0.5-5.0 $\mu \mathrm{M}$ ) or intracellular $\mathrm{Cl}^{-}$concentrations (4-145 mM). Our results present further evidence that dendritic vesicular glutamate release, controlled by novel VGLUT isoforms, provides fast negative feedback at inhibitory neocortical synapses, and demonstrate that glutamate can act as a retrograde messenger in the CNS.

Key words: cannabinoid receptor; inhibitory transmission; interneuron; neocortex; pyramidal cell; vesicular glutamate transporters

\section{Introduction}

Retrograde synaptic signaling provides negative feedback to neurotransmitter release from a nerve terminal by the release of neuroactive substances from the postsynaptic dendrite (for review, see Alger, 2002). Retrograde signaling has also been demonstrated at inhibitory synapses between pyramidal cells and fastspiking, nonaccommodating (FSN) interneurons in layer $2 / 3$ of neocortex (Zilberter, 2000). The effect of retrograde messengers

\footnotetext{
Received Sept. 2, 2003; revised March 17, 2004; accepted April 20, 2004.

This work was supported by European Commission Grant QLG3-CT-2001-02430 (Y.Z.), the Swedish Medical Research Council (T.H.), the Hungarian National Science Fund (F035254) (T.H.), the Hans and Loo Ostermans Foundation (T.H.), and National Institutes of Health Grants DA11322 and DA99286 (K.M.). We thank 0. K. Penz for skilled technical assistance with immunocytochemical procedures.

${ }^{*}$ T.H. and C.H. contributed equally to this work.

Correspondence should be addressed to Dr. Yuri Zilberter, Department of Neuroscience, Karolinska Institutet, Retzius väg 8, B2-2, S-17177 Stockholm, Sweden. E-mail: yuri.zilberter@neuro.ki.se.

DOI:10.1523/JNEUROSCI.4884-03.2004

Copyright $\odot 2004$ Society for Neuroscience $\quad$ 0270-6474/04/244978-11\$15.00/0
}

was mediated via metabotropic glutamate receptors (mGluRs) in the axon terminals of FSN interneurons. These results prompted the suggestion that glutamate might act as a retrograde messenger in inhibitory neocortical synapses. More recent findings, however, show that endocannabinoids act as membrane-diffusible retrograde messengers in the cerebellum (Kreitzer and Regehr, 2001b), hippocampus (Wilson and Nicoll, 2001), and neocortex (Trettel and Levine, 2003), where they suppress neurotransmitter release by acting on presynaptic type 1 cannabinoid (CB1) receptors. Because endocannabinoid synthesis is controlled by mGluR activation (Maejima et al., 2001; Varma et al., 2001), the possible involvement of endocannabinoid signaling at inhibitory synapses between pyramidal cells and FSN interneurons was also proposed (Ludwig and Pittman, 2003).

Here we demonstrate that CB1 receptor-mediated endocannabinoid signaling is not involved in tuning transmission efficacy of inhibitory synapses between FSN interneurons and pyramidal cells. If dendritic exocytosis of glutamate (Zilberter, 2000) under- 
lies retrograde signaling, then both synaptic vesicles and vesicular glutamate transporters (VGLUTs) should be located in subsynaptic dendrites.

Neurotransmitter release at both excitatory and inhibitory synapses requires accumulation of neurotransmitters in synaptic vesicles and their subsequent $\mathrm{Ca}^{2+}$-dependent exocytosis from presynaptic terminals (Masson et al., 1999). Transport of classical neurotransmitters, such as glutamate, into storage vesicles in nerve endings is mediated by VGLUT1 and VGLUT2 (Bellocchio et al., 2000; Takamori et al., 2000a, 2001; Fremeau et al., 2001), which are expressed in subpopulations of glutamatergic neurons throughout the CNS (Fremeau et al., 2001; Fujiyama et al., 2001; Kaneko et al., 2002; Li et al., 2003). In contrast, a third subtype of vesicular glutamate transporters, VGLUT3, exhibiting high structural and functional similarity to VGLUT1 and VGLUT2 (Fremeau et al., 2002; Gras et al., 2002; Schäfer et al., 2002; Takamori et al., 2002), was additionally found in various nonglutamatergic nerve cells, including cholinergic, serotonergic, and GABAergic neurons (Fremeau et al., 2002; Gras et al., 2002; Schäfer et al., 2002; Takamori et al., 2002; Harkany et al., 2003). In addition to its presence in nerve terminals of GABAergic interneurons, VGLUT3 was also localized to membranous structures in dendrites of striatal and hippocampal neurons with interneuron-like morphology (Fremeau et al., 2002; Herzog et al., 2004); however, the physiological significance of VGLUT3 in dendritic compartments is as yet unknown.

We show that VGLUT3-like immunoreactivity, but not VGLUT1 or VGLUT2, is present in the dendrites of pyramidal cells in layer $2 / 3$ of the neocortex. Dual whole-cell recordings provide evidence that modulating VGLUT activity controls retrograde communication at inhibitory synapses between FSN interneurons and pyramidal cells. Our results therefore suggest that glutamate is a retrograde messenger and its release, mediated by novel VGLUT isoforms, from pyramidal cell dendrites can provide fast negative feedback in inhibitory neocortical synapses.

\section{Materials and Methods}

Tissue processing. Experimental procedures were approved by the Ethical Committee on Animal Experiments of Stockholm (N55/2002) and conformed to the European Communities Council Directive (86/609/EEC). Brain slices for electrophysiological studies were prepared from 14- to 18 -d-old Sprague Dawley rats. For immunocytochemistry, young adult male rats (200-250 gm; $n=6$ ) were anesthetized deeply with pentobarbital and perfused transcardially with physiological saline $(50 \mathrm{ml})$ followed by $4 \%$ paraformaldehyde and $0.1 \%$ glutaraldehyde in $0.1 \mathrm{~m}$ phosphate buffer (PB), $\mathrm{pH}$ 7.4. Brains were postfixed in $4 \%$ paraformaldehyde in PB overnight. Cryoprotection of the tissue was achieved by equilibrating in 30\% sucrose in $\mathrm{PB}$, and $40-\mu \mathrm{m}$-thick coronal or sagittal sections were cut on a cryostat microtome and collected in PB.

Patch-clamp recordings. Cortical parasagittal slices $(300 \mu \mathrm{m})$ were prepared as described previously (Markram et al., 1997). Neurons in layer $2 / 3$ of the visual or somatosensory cortex were selected on the basis of morphological features using infrared differential interference contrast video microscopy and subsequent characterization of neuron firing properties. The extracellular solution contained (in $\mathrm{mM}$ ): $135 \mathrm{NaCl}, 2.5$ $\mathrm{KCl}, 2 \mathrm{CaCl}_{2}, 1 \mathrm{MgCl}_{2}, 25 \mathrm{NaHCO}_{3}, 1.25 \mathrm{NaH}_{2} \mathrm{PO}_{4}$, and 25 glucose. The pipette solution contained (in mM): $125 \mathrm{~K}$-gluconate, $20 \mathrm{KCl}, 4 \mathrm{ATP}-\mathrm{Mg}$, $10 \mathrm{Na}$-phosphocreatine, $0.3 \mathrm{GTP}$, and 10 HEPES, pH 7.3.

In pharmacological experiments, the $\mathrm{KCl}$ concentration was varied in the pipette solution with a corresponding substitution of K-gluconate. To inhibit spontaneous excitatory activity of recorded cells during experiments with $4 \mathrm{mM} \mathrm{Cl}^{-}$in the pipette solution, 2-4 $\mu \mathrm{M}$ 2,3-dioxo-6-nitro1,2,3,4-tetrahydrobenzo[f] quinoxaline-7-sulfonamide disodium (Tocris Cookson, Bristol, UK) was added to the bath solution. Evans blue (EB) (500 nм-5 $\mu \mathrm{M}$; Sigma, St. Louis, MO) was directly dissolved in the pipette solution. ( $R$ )-(+)-[2,3-dihydro-5-methyl-3-(4-morpholinylmethyl) pyrrolo[1,2,3-de]-1,4-benzoxazin-6-yl]-1-naphthalenylmethanone mesylate (WIN 55,212-2) and $N$-(piperidin-1-yl)-5-(4-iodophenyl)-1-(2,4dichlorophenyl)-4-methyl-1 $H$-pyrazole-3-carboxamide (AM 251) were obtained from Tocris Cookson and applied in the extracellular solution. Efficacy of the WIN 55,212-2 stock solution was verified in experiments on lamprey spinal cord (Kettunen et al., 2002). Efficacy of AM 251 was tested on unitary connections between layer 5 pyramidal cells $(n=3)$, where AM 251 completely prevented the initiation of long-term depression during a $10 \mathrm{~Hz}$ pairing protocol (Sjöström et al., 2003). All experiments were performed at $32-34^{\circ} \mathrm{C}$.

A conditioning protocol for raising the dendritic $\mathrm{Ca}^{2+}$ concentration was applied as described previously (Zilberter, 2000). A train of 10 action potentials (APs) at $50 \mathrm{~Hz}$ in the pyramidal neuron induced by current injection in the soma caused a transient increase in the dendritic $\mathrm{Ca}^{2+}$ concentration. One or two successive IPSPs in the pyramidal cell were evoked by stimulating the FSN interneuron $250 \mathrm{msec}$ after the postsynaptic burst. Only the first IPSP induced in each stimulation pattern was analyzed. This pattern of sequential presynaptic and postsynaptic stimulation was repeated every $5 \mathrm{sec}$. The paired-pulse ratio (PPR) was calculated as IPSP2/IPSP1, in which IPSP1 and IPSP2 were mean IPSP amplitudes in response to the first and second FSN cell APs, respectively. The mean amplitude of unitary IPSPs was measured from 50 to 100 sweeps.

Connected pairs of pyramidal cells and interneurons were labeled with Alexa Fluor 488 (0.5 mm; Molecular Probes, Leiden, The Netherlands) and biocytin $(0.5 \mathrm{mg} / \mathrm{ml}$; Sigma $)$, respectively.

Data from electrophysiological recordings after pharmacological manipulations were statistically evaluated using Student's $t$ test. Drug efficacy was characterized by determining the degree of inhibition during conditioning that was calculated as the percentage of the mean preconditioning control value. A $p$ level of $<0.05$ was taken as indicative of statistical significance. Data were expressed as means \pm SD.

Immunohistochemical detection of CB1 receptors in brain slices and colocalization with vesicular GABA transporter and VGLUT3. Brain slices were fixed in $4 \%$ paraformaldehyde and $0.1 \%$ glutaraldehyde in $\mathrm{PB}$ overnight at $4^{\circ} \mathrm{C}$. After extensive rinsing in $\mathrm{PB}$, free-floating brain slices were pretreated with $1 \%$ Sudan Black B in $70 \%$ ethanol to quench tissue autofluorescence (Schnell et al., 1999). Specimens were then preincubated in a solution of $2.5 \%$ bovine serum albumin (BSA), $5 \%$ normal donkey serum (NDS; Jackson ImmunoResearch, West Grove, PA), and $0.5 \%$ Triton X-100 in PB for $1 \mathrm{hr}$, which was followed by exposure to the primary antibody $(\mathrm{Ab})$ rabbit anti-CB1 receptor [1:400; directed against a C-terminal sequence (Katona et al., 2001)] that was diluted in a mixture of $5 \%$ dimethylsulfoxide, $0.5 \%$ Triton X-100, $0.1 \%$ BSA, and $1 \%$ NDS in $\mathrm{PB}$ for $48 \mathrm{hr}$ at $4^{\circ} \mathrm{C}$. Thereafter, tissue was rinsed extensively in $\mathrm{PB}$ and incubated with carbocyanine $(\mathrm{Cy}) 2$ - or Cy5-conjugated donkey antirabbit $(9.0 \mu \mathrm{g} / \mathrm{ml})$ secondary antibodies and Cy3-tagged streptavidin $(0.25 \mu \mathrm{g} / \mathrm{ml}$ to reveal neurobiotin labeling; Jackson ImmunoResearch $)$ in $2 \%$ BSA and $0.5 \%$ Triton X-100 in PB overnight at $4^{\circ} \mathrm{C}$. The specificity of $\mathrm{CB} 1$ receptor immunolabeling was verified in control experiments by preadsorption of the $\mathrm{CB} 1$ receptor $\mathrm{Ab}$ with the corresponding glutathione $S$-transferase-coupled fusion protein $(1.0 \mu \mathrm{g} / \mathrm{ml})$ and resulted in the complete absence of immunolabeling.

To reveal the distribution of CB1 receptors, vesicular GABA transporter (VGAT), and VGLUT3 and their spatial relationship to pyramidal cells in the neocortex, coronal sections were preincubated in a solution of 2\% BSA, 5\% NDS (Jackson ImmunoResearch), and 0.3\% Triton X-100 in $\mathrm{PB}$ for $1 \mathrm{hr}$ and subsequently exposed to selected combinations of primary antibodies, such as guinea pig anti-VGAT (1:1000; Chemicon, Temecula, CA), rabbit anti-CB1 receptor (1:400) (Katona et al., 2001), guinea pig anti-VGLUT3 (1:1000) (Harkany et al., 2003), and mouse anti-SMI 32 (1:1000; selectively recognizing nonphosphorylated neurofilaments in pyramidal cells; Affinity Research Products, Nottingham, UK) (Pike et al., 1993), which were diluted in 1\% NDS, 0.1\% BSA, and $0.3 \%$ Triton $\mathrm{X}-100$ in $\mathrm{PB}$ for $48 \mathrm{hr}$ at $4^{\circ} \mathrm{C}$. After extensive rinsing of tissue samples, immunoreactivities were revealed by $\mathrm{Cy} 2$-conjugated donkey anti-mouse, Cy3-tagged donkey anti-rabbit, and Cy5-labeled donkey anti-guinea pig secondary antibodies $(9.0 \mu \mathrm{g} / \mathrm{ml}, 2 \%$ BSA in PB, $2 \mathrm{hr})$. 
Target-specific isolation of interneuron subsets and Western blotting. Tissue was obtained from Sprague Dawley rats on postnatal day 4. After dissection of neocortical layers 1-3, the samples were enzymatically dissociated $[0.1 \%$ trypsin in PBS (PBS, $0.01 \mathrm{M}, \mathrm{pH} 7.4$ ) containing $0.5 \%$ glucose] for $15 \mathrm{~min}$ at $37^{\circ} \mathrm{C}$. Next, the tissue was triturated in Neurobasal-A medium (Invitrogen, Carlsbad, CA) supplemented with DNase $(0.5 \mathrm{mg} / \mathrm{ml}$; Promega, Madison, WI $)$ and centrifuged $\left(600 \mathrm{rpm}, 10 \mathrm{~min}, 25^{\circ} \mathrm{C}\right)$, and the pellet was washed twice in Neurobasal-A medium. To isolate $\mathrm{CB} 1$ receptor-expressing interneurons, $\sim 3 \times 10^{7}$ superparamagnetic polystyrene beads covalently bound to affinity-purified sheep anti-rabbit IgG $(\sim 30 \mu \mathrm{l} ; \mathrm{M}-280$, Dynal Biotech, Oslo, Norway) were washed in PBS containing $0.1 \%$ BSA (PBS-BSA) and subsequently incubated with $15 \mu \mathrm{g}$ of rabbit anti$\mathrm{CB} 1$ receptor $\mathrm{Ab}$ [recognizing the extracellular $\mathrm{N}$ terminus (Katona et al., 1999)] overnight at $4^{\circ} \mathrm{C}$ under continuous agitation in PBS-BSA. Anti-CB1 receptor Ab-conjugated beads were then collected with a magnetic particle concentrator (MPC, Dynal Biotech), washed in PBSBSA, and incubated separately with aliquots of the cell suspension in Neurobasal-A medium for $1.5 \mathrm{hr}$ at room temperature under continuous shaking. Cells bound to Ab-bead conjugates were then isolated by placing the suspension in MPC-1 for 2-3 min. Isolated cells were washed in Neurobasal-A medium. Subsequently, equal amounts of $\mathrm{CB} 1$ receptorpositive interneurons and of cells of the remnant cortical tissue $(800,000)$ were lysed using a modified radioimmunoprecipitation buffer containing (final concentrations): $50 \mathrm{~mm}$ Tris$\mathrm{HCl}, \mathrm{pH} 7.4,1 \%$ Triton X-100, $0.25 \% \mathrm{Na}-$ deoxycholate, $150 \mathrm{~mm} \mathrm{NaCl}, 1$ mm EDTA, $1 \mathrm{~mm}$ $\mathrm{NaF}, 1 \mathrm{~mm} \mathrm{Na} \mathrm{NO}_{4}$, and a mixture of protease inhibitors (Complete, EDTA-free, Roche, Mannheim, Germany). Dissociated crude fractions of layer 1-3 of the neocortex (P4) were used as control. Next, samples were sonicated and lysates were denatured in $5 \times$ Laemmli buffer. Samples of identical volume $(5 \mu \mathrm{l})$ were
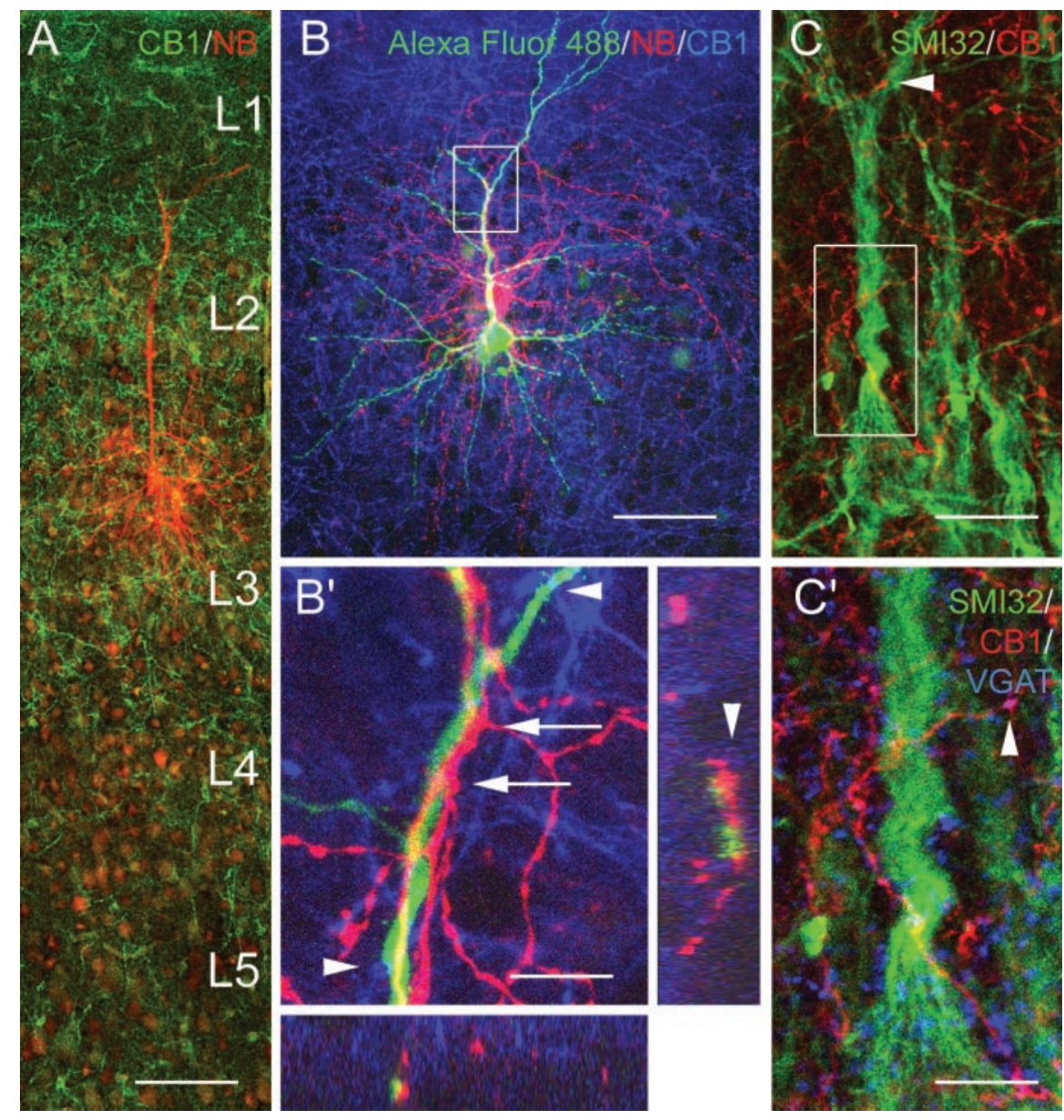

Figure 1. $\quad$ B1 receptors are not detectable in FSN interneuron-pyramidal cell synapses. $A$, The highest density of $C B 1$ immunoreactive fibers was demonstrated in layer 2/3 of the neocortex, whereas CB1-positive cells were found predominantly in deep cortical layers. A neurobiotin-labeled FSN interneuron-pyramidal cell pair appears in red. L1- L5 denote cortical layers. $B$, Colocalization of $C B 1$ receptors with identified neuron pairs demonstrated a lack of $C B 1$ immunoreactivity at inhibitory connections $(\square)$. $B^{\prime}$, High-power reconstruction of particular inhibitory contacts along the $z$-axis revealed CB1 receptor-negative contacts between FSN interneurons and pyramidal cells. Arrows denote CB1-negative synaptic contacts between identified cells, whereas arrowheads indicate separate CB1-immunoreactive synapses of as yet unidentified origin. NB, Neurobiotin. C, Pyramidal cells receive prominent $C B 1$ receptor-immunoreactive innervation on the proximal segment of their apical dendrites, with only a subset being immunoreactive for VGAT ( $\left.C^{\prime}\right)$. Scale bars: $A, 120 \mu \mathrm{m} ; B, 65 \mu \mathrm{m} ; B^{\prime}, 12 \mu \mathrm{m} ; C, 15 \mu \mathrm{m} ; C^{\prime}, 7 \mu \mathrm{m}$. analyzed by PAGE ( $4 \%$ stacking and $10 \%$ resolving gels) and electrical transfer of proteins onto polyvinylidene difluoride membrane using Towbin's buffer. After blocking in 1\% gelatin in Tris- $\mathrm{HCl}$ buffer ( $50 \mathrm{~mm}, \mathrm{pH} 7.4$ ) containing $0.1 \%$ Tween 20 (TBS-T) for $1 \mathrm{hr}$, the membranes were exposed to primary antibodies [rabbit antiVGLUT3, 1:4000 (Fremeau et al., 2002), and rabbit anti-VGAT, 1:2000 (Takamori et al., 2000b) (Synaptic Systems, Göttingen, Germany)], overnight at $4^{\circ} \mathrm{C}$. The neuronal marker $\beta$-III-tubulin (1:1000; Promega) was used to control loading efficacy. After they were washed in TBS-T, the membranes were incubated in a solution containing a goat antirabbit $\mathrm{Ab}$ coupled to alkaline phosphatase (1:10,000; Amersham Biosciences, Uppsala, Sweden), and bands were visualized using the enhanced chemiluminescence method according to the manufacturer's instructions (Amersham Biosciences).

Immunofluorescence localization of VGLUTs in pyramidal cells. Immunohistochemical procedures were applied to free-floating sections and started by extensive rinsing of tissue samples in PB. Subsequently, sections were exposed to a blocking solution containing 5\% NDS (Jackson ImmunoResearch) and $2 \% \mathrm{BSA}$ in $\mathrm{PB}$, to which $0.3 \%$ Triton X-100 had been added, for $1 \mathrm{hr}$. Double-labeling experiments with selected combinations of antibodies recognizing nonphosphorylated neurofilaments and microtubule-associated protein 2 (MAP2) with VGLUT1, VGLUT2, or VGLUT3 were performed by incubating the sections in mixtures of antibodies, such as mouse anti-SMI32, mouse anti-SMI311 [1:1000; Affinity Research Products (Pike et al., 1993; Preuss et al., 1997)], rabbit anti-MAP2 (1:600; Chemicon), rabbit anti-VGLUT1 (1:2000), rabbit anti-VGLUT2 (1:1000; both obtained from Synaptic Systems), guinea pig anti-VGLUT3 $(1: 1000-1: 10,000)$, or rabbit anti-VGLUT3 [1:500-1: 1000 (Fremeau et al., 2002; Harkany et al., 2003)], in PB containing 1\% NDS, $0.1 \%$ BSA, and $0.3 \%$ Triton X-100 for $48 \mathrm{hr}$ at $4^{\circ} \mathrm{C}$. After repeated rinsing of the sections, immunoreactivities were visualized with combinations of affinity-purified secondary antibodies raised in donkey and tagged with Cy2 or Cy3 as fluorophores $[9.0 \mu \mathrm{g} / \mathrm{ml}$ (Jackson ImmunoResearch) in $2 \% \mathrm{BSA}$-containing $\mathrm{PB} ; 2 \mathrm{hr}$ at room temperature). Control experiments were performed by omission of primary antibodies and resulted in the absence of stained fibers and perikarya. In addition, preadsorption of both anti-VGLUT3 primary antibodies with 20 or 40 $\mu \mathrm{g} / \mathrm{ml}$ fusion protein (Fremeau et al., 2002; Harkany et al., 2003) resulted in the complete absence of the immunosignal. Finally, sections were rinsed extensively in $\mathrm{PB}$, dipped briefly in distilled water, mounted onto fluorescence-free slides, air-dried, and coverslipped with Entellan (Merck, Darmstadt, Germany).

Immunoelectron microscopy localization of VGLUT3. Tissue samples were prepared, and pre-embedding VGLUT3 labeling using the immunoperoxidase method was performed as described previously (Chaudhry 
A
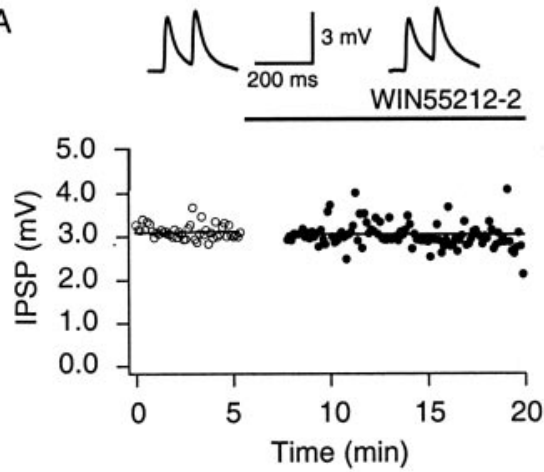

WIN55212-2

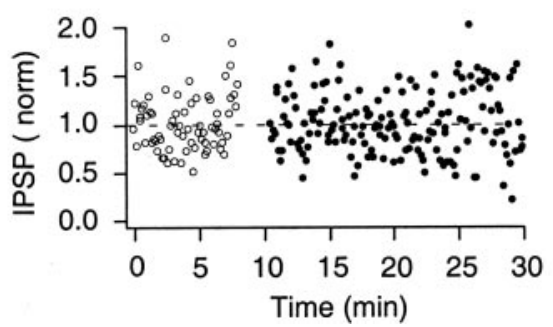

B
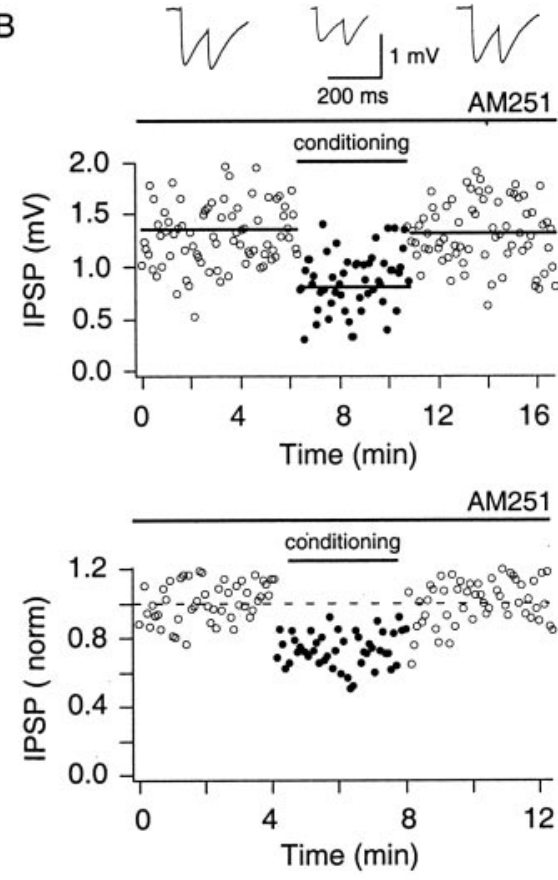

Figure 2. Endocannabinoid signaling via CB1 receptors does not affect retrograde signaling between FSN interneurons and pyramidal cells in layer 2/3 of the neocortex. (B1 receptor agonist and antagonist do not affect synaptic transmission. $A$, Dual whole-cell recordings showed that the cannabinoid receptor agonist WIN 55,212-2 (1 $\mu \mathrm{m})$ did not influence IPSPs in pyramidal cells (20 mm $\left[\mathrm{Cl}^{-}\right]$in the pipette solution). B, Trains of backpropagating APs induced IPSP depression in the presence of CB1 receptor antagonist AM $251(4 \mu \mathrm{M})$. Four millimolars of $\left[\mathrm{Cl}^{-}\right]$in the pipette solution was used. Top panels show selected experiments. Horizontal lines correspond to the mean amplitude of IPSPS, and corresponding records are shown on the top. Bottom panels, Each circle represents the mean amplitude from all experiments $(A, n=6 ; B, n=3)$. In each experiment, the IPSP amplitudes were normalized to the average amplitude in control. Subsequently, at equal times during the experimental protocol, normalized IPSPs were averaged.

et al., 1998; Fremeau et al., 2002). Rabbit anti-VGLUT3 primary Ab and biotinylated secondary donkey anti-rabbit IgG (Jackson ImmunoResearch) were diluted as 1:200-1:800 and 1:100, respectively. Subsequently, $\sim 1-3 \mathrm{~mm}^{3}$ tissue blocks were excised from immunostained brain sections, postfixed in $2.5 \%$ glutaraldehyde, immersed in $10 \mathrm{mg} / \mathrm{ml}$ $\mathrm{OsO}_{4}$ for $30 \mathrm{~min}$, dehydrated in graded ethanol and propylene oxide, and embedded in Durcupan ACM. Contrast enhancement of ultrathin sections was achieved by incubation with $10 \mathrm{mg} / \mathrm{ml}$ uranyl acetate for 10 $\mathrm{min}$ and $3 \mathrm{mg} / \mathrm{ml}$ lead citrate for $1 \mathrm{~min}$. Electron microscopy analysis was performed using a Phillips CM10 electron microscope.

Laser-scanning microscopy. Analysis of our specimens was performed using a confocal laser-scanning microscope (model 510, Zeiss) equipped with argon (488 nm) and helium-neon (543 nm and $633 \mathrm{~nm}$ ) lasers and appropriate excitation and emission filters for maximum separation of Cy2, Cy3, and Cy5 signals. Emission wavelengths were limited to 505$530 \mathrm{~nm}$ (bandpass filter, Cy2), 560-610 nm (bandpass filter, Cy3), and $>650 \mathrm{~nm}$ (long-pass filter, Cy5), respectively. Analysis of identified synapses along the $z$-axis was performed by capturing consecutive images with a $60 \mu \mathrm{m}$ pinhole size at $63 \times$ primary magnification $(<0.6 \mu \mathrm{m}$ optical slice) and $2.5 \times$ optical zoom as described previously (Harkany et al., 2003; Holmgren et al., 2003). The infrared signal (Cy5) was color coded in blue. Projection images were established using Zeiss LSM Viewer shareware software (version 3.0). Images were then processed using Paint Shop Pro (version 8.0; Jasc, Eden Prairie, MN), and panels were assembled in Adobe Photoshop (version 7.0; Adobe, San Jose, CA).

\section{Results}

CB1 receptor-mediated endocannabinoid signaling is not involved in retrograde synaptic communication between FSN interneurons and pyramidal cells

Retrograde synaptic communication with nonquantal release of endocannabinoids, acting on presynaptic $\mathrm{CB} 1$ receptors (Devane et al., 1988), has been demonstrated at inhibitory hippocampal (Wilson and Nicoll, 2001) and neocortical connections (Trettel and Levine, 2003) and both inhibitory (Kreitzer and Regehr, 2001b) and excitatory (Kreitzer and Regehr, 2001a) synapses in the cerebellum. Do endocannabinoids also participate in the control of efficacy of inhibitory synapses between FSN interneurons and pyramidal cells? To address this question, we first examined the pattern of CB1 receptor immunoreactivity in layer $2 / 3$ of the neocortex, with a particular interest in the presence, or absence, of CB1 receptors in the axons of FSN interneurons. CB1 receptor immunostaining in cortical slices revealed a dense network of CB1 receptor-immunoreactive fibers and a few CB1 receptor-immunopositive somata (Fig. $1 A$ ). The highest density of CB1 receptor-positive fibers was apparent in layer 2/3 (Tsou et al., 1998). FSN interneurons formed multiple synapses $(n=7 \pm 1$ in three identified cell pairs) on neighboring pyramidal cells (Fig. 1B). The combination of CB1 receptor immunohistochemistry with intracellular labeling of synaptically connected cells revealed a lack of CB1 receptors in presynaptic terminals of FSN interneurons (Fig. $1 B, B^{\prime}$ ). In addition, only a subset of $\mathrm{CB} 1$ receptor-labeled terminals on pyramidal cell dendrites colocalized with VGAT (Fig. 1C, $C^{\prime}$ ), suggesting that non-GABAergic, as yet unidentified nerve endings harboring $\mathrm{CB} 1$ receptors also exist in layer $2 / 3$ of the neocortex.

Electrophysiological recordings verified the lack of endocannabinoid-mediated retrograde signaling in FSN interneuronpyramidal cell pairs (Fig. 2). IPSPs were measured under control conditions and in the presence of the selective cannabinoid receptor agonist WIN 55,212-2 (1 $\mu \mathrm{M})$. WIN 55,212-2 did not affect inhibitory transmission, as indicated by the unchanged mean IPSP amplitude $[0.93 \pm 1.07 \mathrm{mV}$ (control) vs $0.96 \pm 1.06 \mathrm{mV}$ (WIN 55,212-2); $n=6$ ] (Fig. 2A). A higher WIN 55,212-2 concentration $(5 \mu \mathrm{M})$ did not affect synaptic transmission either. The mean IPSP amplitude was $0.45 \pm 0.13 \mathrm{mV}$ in control and $0.48 \pm$ $0.16 \mathrm{mV}$ in the presence of WIN 55,212-2 with $4 \mathrm{mM} \mathrm{Cl}^{-}$in the pipette solution ( $n=3$; data not shown). Moreover, synaptic depression during conditioning could still be induced in the presence of the CB1 receptor antagonist AM $251(4 \mu \mathrm{M})$ in the extracellular solution (Fig. $2 B$ ) when the mean IPSP amplitude decreased to $68 \pm 8 \%$ of control during conditioning $(n=3)$. We therefore concluded that FSN terminals do not contain CB1 receptors and endocannabinoids do not contribute to retrograde signaling at inhibitory synapses between FSN interneurons and pyramidal cells.

\section{VGLUT3 is present in distinct groups of cortical cells}

Recent in situ hybridization studies have demonstrated the presence of VGLUT3 mRNA transcripts in various cell populations, including both glutamatergic and non-glutamatergic neurons, in rodent forebrain (Fremeau et al., 2002). In the rat cerebral cortex, abundant VGLUT3 mRNA was detected in multiple cortical lam- 
inas, but strongest labeling was achieved in layer 2/3. Prominent VGLUT3 expression was confined to a subset of putative interneurons, whereas pyramidal cells hybridized at lower levels (Fremeau et al., 2002).

Although previous studies addressing the distribution of VGLUT3 protein invariably noted high VGLUT3 levels in a distinct subset of GABAergic interneurons in the neocortex (Fremeau et al., 2002; Gras et al., 2002; Schäfer et al., 2002; Herzog et al., 2004), relatively few data support the existence of other neuron populations with low VGLUT3 expression (Fremeau et al., 2002, 2004). Importantly, VGLUT3immunoreactive cortical interneurons belong to the cholecystokinin (CCK)containing subset of GABAergic cells (M. B. Dobszay and T. Harkany, unpublished observations) and coexpress $\mathrm{CB1}$ receptors (Fig. $3 A, B$ ).

Selective expression of $\mathrm{CB} 1$ receptors on VGLUT3-containing interneurons allows target-specific isolation of this interneuron population from the neocortex $(\mathrm{P}$. Berghuis, M. B. Dobszay, K. M. Sousa, P. P., Mager, W. Härtig, T. J. Görcs, Y. Zilberter, P. Ernfors, and T. Harkany, unpublished observations). Therefore, we used this approach to determine whether VGLUT3 protein can still be detected in samples of cortical tissue after removal of VGLUT3-containing interneurons. The isolation procedure was performed at $\mathrm{P} 4$, when VGLUT3 protein is present in the neocortex (Schäfer et al., 2002). As Figure 3C shows, both VGLUT3 and VGAT, an invariable marker of GABAergic neurons, were abundantly expressed in layers 1-3 of the neocortex. GABAergic interneurons expressing CB1 receptors harbored significant amounts of VGLUT3 together with low levels of VGAT. In contrast, fast spiking (FS) cells contained high amounts of VGAT, whereas their VGLUT3 protein content was under our detection threshold (data not shown). Importantly, significant amounts of VGLUT3 protein, together with VGAT, were still found in the remnant cell pool prepared from neocortical layers 1-3. Our data thus suggest that VGLUT3 may be present in cortical neurons distinct from subsets of GABAergic interneurons.

\section{VGLUT3 is present in pyramidal cell dendrites}

To identify whether VGLUT3 protein is localized to pyramidal cells in layer $2 / 3$ of neocortex, and whether its subcellular distribution is consistent with a putative function in retrograde neurotransmission, we first performed multiple immunofluorescence labeling using combinations of anti-VGLUT3 antisera raised in rabbit or guinea pig and morphological markers of pyramidal cells. Both anti-VGLUT3 antibodies revealed identical staining patterns in rat neocortex. In particular, intense VGLUT3like immunoreactivity was present in the somata and axons of a subset of interneuron-like cells (Fig. 4A). VGLUT3-like immunoreactivity, albeit of lower intensity, was demonstrated in neurons with pyramidal cell-like morphology (Fig. 4A, B), confirming the known distribution pattern of VGLUT3 mRNA in this region (Fremeau et al., 2002). High-resolution confocal laserscanning microscopy substantiated the presence of VGLUT3-like immunolabeling in the somata and dendritic arbor of pyramidal cells (Fig. 4B-D). VGLUT3 signal was localized to proximal, primary, and secondary compartments of apical and basal dendrites (Fig. 4C,D) in pyramidal cells. VGLUT3-like labeling was evident in dendritic shafts, the primary site of inhibitory synapses (Freund and Gulyas, 1991), but not in dendritic spines known to predominantly receive excitatory synaptic contacts (Baude et al., 1995). Occasionally, VGLUT3-immunoreactive terminals with a presumed origin in interneurons were in close apposition to VGLUT3-containing dendrites (Fig. 4D-D").

The localization of VGLUT3-like immunoreactivity in proximal dendritic segments of pyramidal cells coincided with a dense GABAergic innervation (Fig. 5A,B), including subsets of FS interneurons (Fig. 5C,D) (Wang et al., 2002). FS cell terminals were frequently found in close apposition to the apical dendritic shaft of pyramidal cells, suggesting a possible involvement of VGLUT3 in signaling mechanisms between pyramidal cells and interneurons.

\section{Subcellular localization of VGLUT3-like immunoreactivity in pyramidal cells}

The subcellular distribution of all known vesicular neurotransmitter transporters reflects their function to concentrate neurotransmitters in synaptic vesicles (Chaudhry et al., 1998; Masson et al., 1999; Bellocchio et al., 2000; Takamori et al., 2000a,b; Fremeau et al., 2001, 2002). To determine whether the spatial distribution of VGLUT3 in apical dendrites of pyramidal cells could underlie its functional involvement in the control of retrograde synaptic transmission, we localized VGLUT3-like immunoreactivity by immunoelectron microscopy. On the electron microscopic level, VGLUT3 appears at two locations in neurons. 

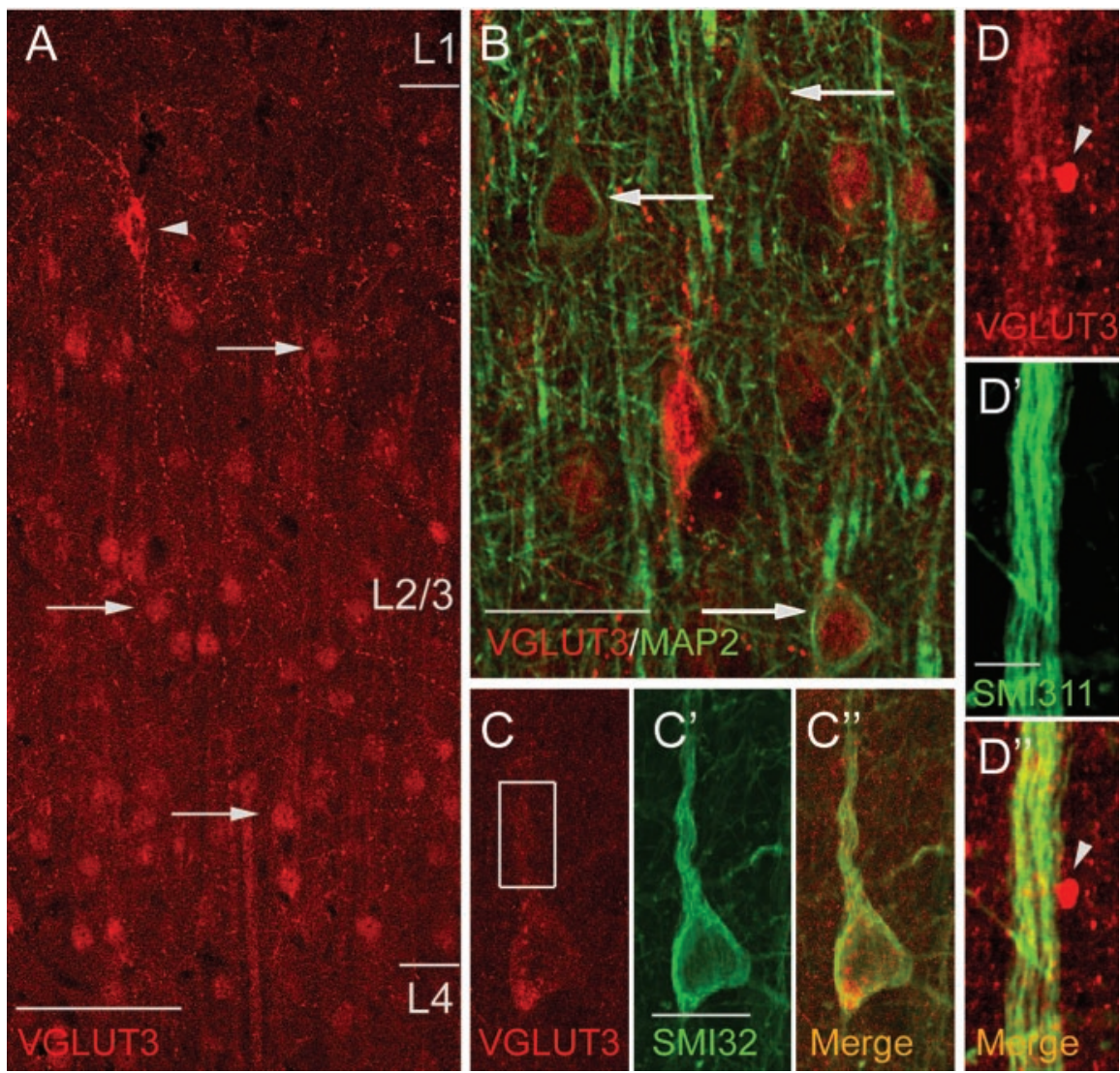

Figure 4. VGLUT3-like immunoreactivity is present in dendrites of pyramidal cells in layer $2 / 3$ of neocortex. $A$, Intense VGLUT3 immunoreactivity in interneuron-like cells (arrowhead) and in their processes was found scattered in layer 2/3 of neocortex concomitant with VGLUT3-like labeling in neurons with apparent pyramidal morphology (arrows). Significant labeling of apical dendrites was evident. $B$, Laser-scanning microscopy demonstrated the presence of VGLUT3-like immunoreactivity in populations of putative pyramidal cells immunoreactive for microtubule-associated protein 2 (arrows). C-C", High-power image of a pyramidal cell in layer 2/3 of the neocortex with perisomatic and dendritic VGLUT3-like immunoreactivity. Open square indicates the general localization of $D-D^{\prime \prime} . D-D^{\prime \prime}$, VGLUT3-like immunoreactivity in the apical dendritic shaft of a pyramidal cell. Arrowhead denotes VGLUT3-like immunoreactive terminal with a presumed origin in interneurons. Optical slice thickness $=1.7 \mu \mathrm{m}(A), 1$ $\mu \mathrm{m}(B)$, and $0.6 \mu \mathrm{m}(C, D)$. L1-L4 denote cortical layers. Scale bars: $A, 65 \mu \mathrm{m} ; B, 28 \mu \mathrm{m} ; C^{\prime}, 15 \mu \mathrm{m} ; D^{\prime}, 3 \mu \mathrm{m}$.
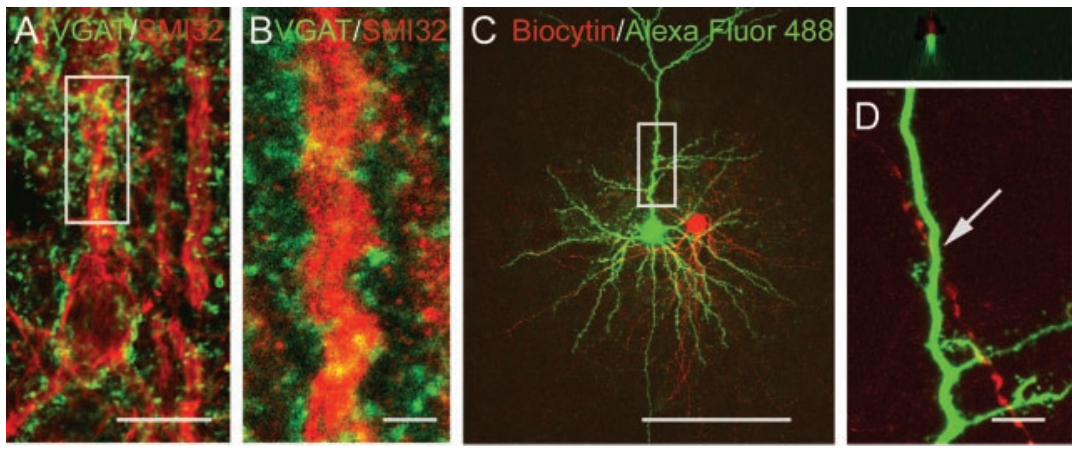

Figure 5. Pyramidal cells in layer $2 / 3$ of the neocortex receive prominent GABAergic innervation on apical dendrites. $A, V G A T$ immunolabeling revealed GABAergic synapses aligning the proximal segment of the apical dendritic tuft of pyramidal cells. Open square in $A$ corresponds to image in $B$. C, Localization of inhibitory connections of FSN interneurons on pyramidal cells in layer $2 / 3$. $D$, Synaptic contact (arrow) was demonstrated on the apical dendrite of a pyramidal cell. Scale bars: $A, 18 \mu \mathrm{m} ; B, 4 \mu \mathrm{m} ; C, 200$ $\mu \mathrm{m} ; D, 10 \mu \mathrm{m}$.

Axon terminals of VGLUT3-immunoreactive interneurons were found scattered in layer $2 / 3$ and were densely stained for the transporter (Fig. 6A). In addition, VGLUT3-like immunoreactivity was present in dendrites of pyramidal cells (Fig. $6 A-C$ ), and vesicle-like structures labeled for this transporter were tightly

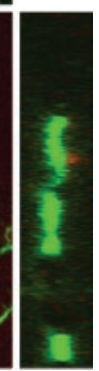

associated with postsynaptic densities in subsynaptic dendrites (Fig. $6 B, C$ ). In accordance with our results obtained by laser-scanning microscopy, VGLUT3-like labeling was present in dendritic shafts (Fig. 6C).

\section{Pyramidal cell dendrites lack VGLUT1} and VGLUT2 immunoreactivity

VGLUT1 and VGLUT2 were previously found localized to terminals of mostly nonoverlapping subsets of glutamatergic neurons throughout the CNS, with VGLUT1 being the predominant form in neocortex (Fremeau et al., 2001). To verify that the cellular distribution of VGLUT1 and VGLUT2 is limited to axonal endings in layer $2 / 3$ of the neocortex, we used multiple immunofluorescence labeling for VGLUT1 or VGLUT2 combined with antibodies (SMI32 and SMI311) directed against nonphosphorylated neurofilament epitopes in pyramidal cells (Pike et al., 1993; Preuss et al., 1997). Although pyramidal cells received multiple VGLUT1- (Fig. 7A,B) or VGLUT2-immunoreactive synapse-like contacts (Fig. 7C,D), neither VGLUT1 nor VGLUT2 was present in the dendritic arbor of pyramidal cells (Fig. 7 B,D). Our data thus indicate that VGLUT3 is the only isoform of known VGLUTs present in dendrites of pyramidal cells.

\section{Modulation of vesicular glutamate uptake affects retrograde signaling} In layer $2 / 3$ of the neocortex, microcircuits of reciprocally interconnected glutamatergic pyramidal cells and GABAergic interneurons, including FSN cells (Zilberter, 2000), are present (Buhl et al., 1997; Markram et al., 1998; Reyes et al., 1998; Zilberter, 2000; Rozov et al., 2001; Wang et al., 2002; Holmgren et al., 2003). It had been hypothesized previously that glutamate release from pyramidal cell dendrites is involved in the regulation of inhibitory transmission by retrograde synaptic signaling, because mGluR agonists suppressed GABA exocytosis from FSN axon terminals whereas mGluR antagonists prevented retrograde signaling (Zilberter, 2000). These findings, coupled with VGLUT3-like immunoreactivity in dendrites of glutamatergic pyramidal cells, prompted us to study whether VGLUTmediated uptake of glutamate into secretory vesicles could underlie retrograde synaptic communication between pyramidal cells and FSN interneurons. We therefore tested the effect of modulating VGLUT activity in a postsynaptic pyramidal cell on neurotransmitter release from FSN interneurons.

Dyes structurally related to glutamate, such as a biphenyl derivative of 1,3-naphthalene disulfonic acid known as Evans blue, 
are potent, competitive VGLUT antagonists in the nanomolar range $\left(\mathrm{EB}: \mathrm{IC}_{50}=\right.$ $87 \mathrm{~nm}$ ) (Roseth et al., 1995; Bellocchio et al., 2000; Schäfer et al., 2002). In addition, VGLUT subtypes are sensitive to changes in the intracellular $\mathrm{Cl}^{-}$concentration $\left(\left[\mathrm{Cl}^{-}\right]_{\mathrm{i}}\right)$ (Bellocchio et al., 2000; Schäfer et al., 2002). VGLUT-mediated glutamate uptake is maximal at $1-4 \mathrm{~mm}\left[\mathrm{Cl}^{-}\right]_{\mathrm{i}}$, whereas an increase in $\left[\mathrm{Cl}^{-}\right]_{\mathrm{i}}$ leads to inhibition of VGLUT function in a dosedependent manner (Bellocchio et al., 2000). Maximum inhibition (of $\sim 80 \%$ ) is achieved above $140 \mathrm{~mm}\left[\mathrm{Cl}^{-}\right]_{\mathrm{i}}$. We therefore used EB and varying $\left[\mathrm{Cl}^{-}\right]_{\mathrm{i}}$ as a means to modulate glutamate transport in pyramidal cells.

Dual whole-cell recordings were performed in pyramidal cell-FSN interneuron pairs with a standard conditioning paradigm (Zilberter et al., 1999; Zilberter, 2000). First, we initiated retrograde signaling by dendritic $\mathrm{Ca}^{2+}$ influx induced by a train $(50 \mathrm{~Hz})$ of 10 backpropagating APs in pyramidal cell dendrites in the presence of $4 \mathrm{~mm}\left[\mathrm{Cl}^{-}\right]_{\mathrm{i}}$ in the pipette solution and recorded unitary IPSPs $250 \mathrm{msec}$ afterward. The mean IPSP amplitude decreased during conditioning by AP trains to $51 \pm$ $16 \%$ of control $(n=5)$ (Fig. $8 \mathrm{~A})$. Thus, application of $4 \mathrm{~mm}\left[\mathrm{Cl}^{-}\right]_{\mathrm{i}}$ in pyramidal cells resulted in an increase of synaptic depression $(p<0.05 ; n=6)$ during conditioning as compared with IPSP depression

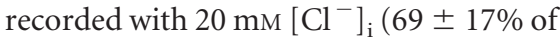
control; $n=10$ ) (Zilberter, 2000).

Intracellular application of EB $(1 \mu \mathrm{M})$ in pyramidal cells abolished synaptic depression during conditioning, inducing IPSP potentiation instead $(125 \pm 18 \%$ of control; $p<0.01$ vs $\left.4 \mathrm{~mm}\left[\mathrm{Cl}^{-}\right]_{\mathrm{i}} ; n=4\right)$ (Fig. $8 \mathrm{~B}$ ). In experiments with both $\mathrm{EB}(5$ $\mu \mathrm{M})$ and $20 \mathrm{mM} \mathrm{Cl}^{-}$in the pipette solution, conditioning resulted in a strong potentiation of IPSPs (Fig. $8 C$ ) with a mean IPSP amplitude of $191 \pm 10 \%$ of control $(p<$ 0.01 vs $\left.4 \mathrm{~mm}\left[\mathrm{Cl}^{-}\right]_{\mathrm{i}} ; n=6\right)$. A 10 -fold lower EB concentration $(500 \mathrm{nM})$ in the presence of $20 \mathrm{mM} \mathrm{Cl}^{-}$in the pipette solution still abolished IPSP depression during conditioning and induced IPSP potentiation, although of a smaller magnitude ( $119 \pm 27 \%$ of control; $p<0.05$ vs $4 \mathrm{mM}\left[\mathrm{Cl}^{-}\right]_{\mathrm{i}} ; n=4$; data not shown) than that observed at $5 \mu \mathrm{M}$ EB. IPSP potentiation was most likely expressed postsynaptically because the PPR did not change with IPSP potentiation $[0.70 \pm 0.11$ (control) and $0.72 \pm 0.12$ (conditioning) $(n=8)]$.

Finally, we tested the effect of $145 \mathrm{~mm}\left[\mathrm{Cl}^{-}\right]_{\mathrm{i}}$, known to significantly inhibit VGLUT function (Bellocchio et al., 2000), on the efficacy of retrograde signaling. Conditioning with this $\left[\mathrm{Cl}^{-}\right]_{\mathrm{i}}$ induced potentiation of IPSPs (Fig. $8 D$ ) with a mean IPSP amplitude of $120 \pm 21 \%$ of control $\left(p<0.01 \mathrm{vs} 4 \mathrm{~mm}\left[\mathrm{Cl}^{-}\right]_{\mathrm{i}} ; n=4\right)$. Thus, our findings provide evidence that accumulation of glutamate in storage vesicles, likely controlled by VGLUT3, and subsequent dendritic glutamate release mediate retrograde signaling between FSN interneurons and pyramidal cells.

\section{Discussion}

Retrograde synaptic signaling in neocortex

Neurotransmitter release from dendrites implicated in the feedback regulation of afferent activity in various brain regions has been investigated extensively over the past decade (for review, see Alger, 2002; Ludwig and Pittman, 2003). Endocannabinoid signaling is the most thoroughly studied mechanism underlying retrograde synaptic communication (Alger, 2002). In particular, endocannabinoids were identified as retrograde messengers in cerebellar Purkinje (Kreitzer and Regehr, 2001a) and hippocampal pyramidal cell (Wilson and Nicoll, 2001) synapses, in which short-term retrograde signaling was first observed by Llano et al. (1991) and Pitler and Alger (1992). Endocannabinoids are membrane-diffusible messengers, and thus their dendritic release does not require morphologically defined active zones (Alger, 2002). Accordingly, endocannabinoid effects are not confined to specific synapses, and once synthesized, they can affect populations of neurons (Wilson and Nicoll, 2001). Endocannabinoid synthesis is triggered by mGluR activation (Maejima et al., 2001; 
A $4 \mathrm{mM} \mathrm{Cl}^{-}$
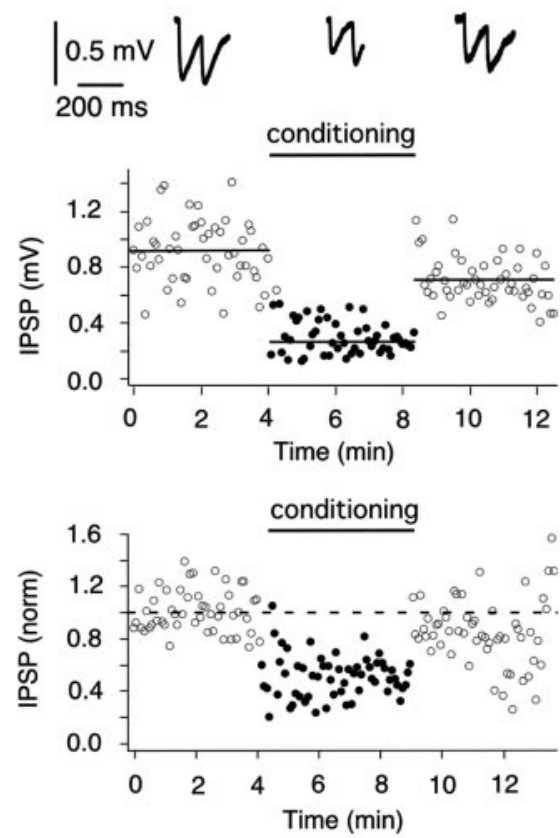

C
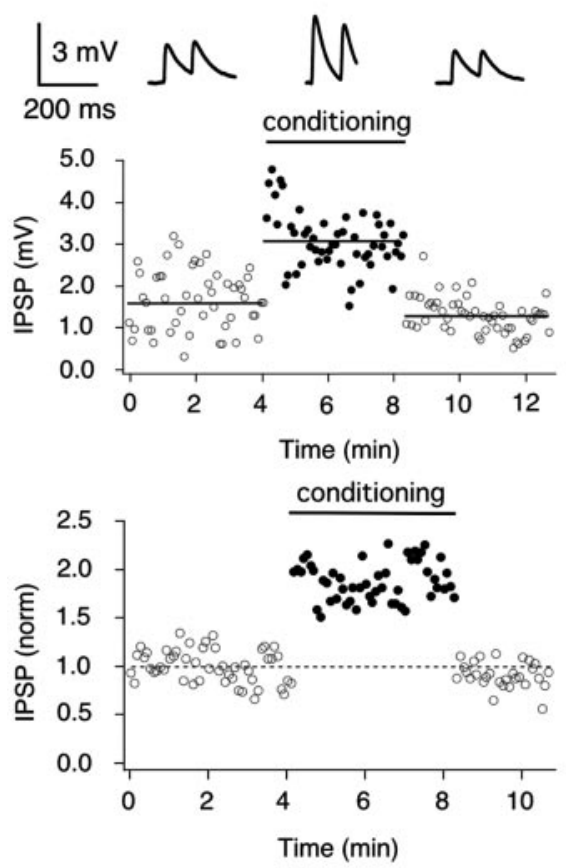

B
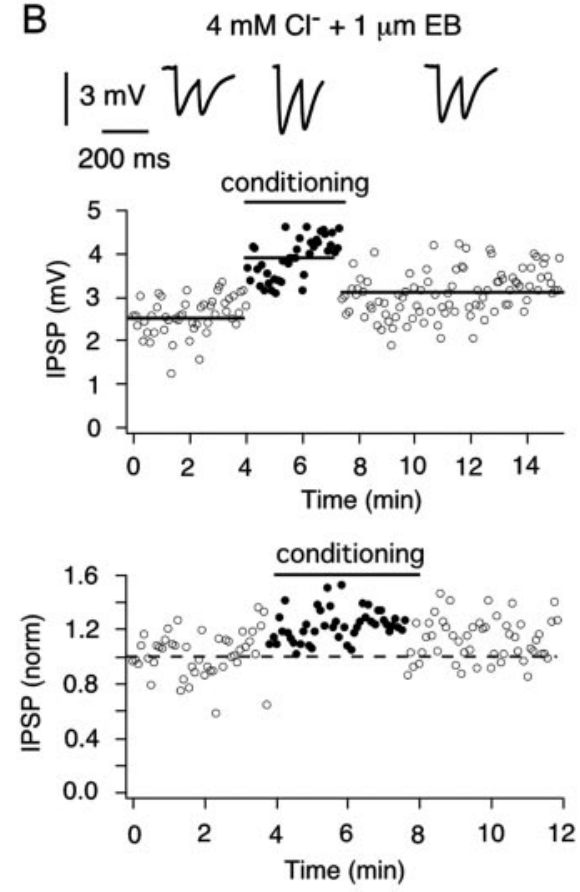

D
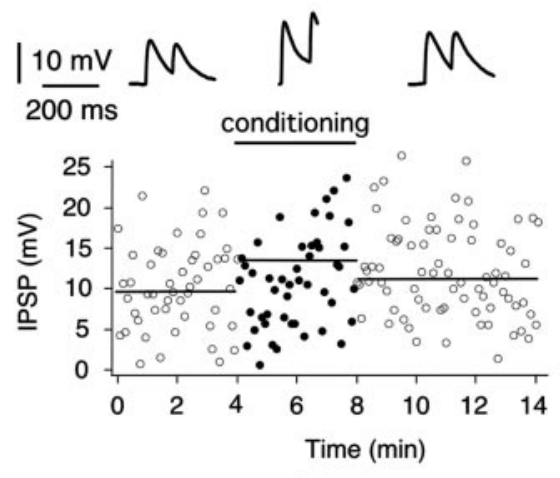

conditioning

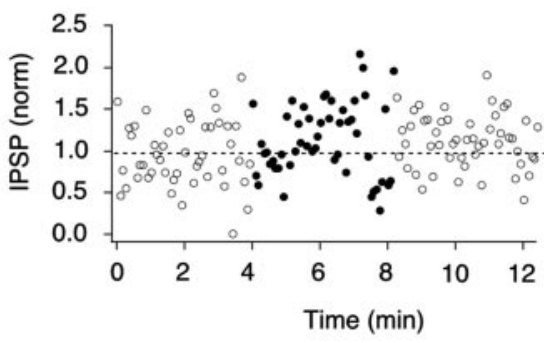

Figure 8. Inhibition of VGLUT-mediated glutamate uptake suppresses retrograde signaling in FSN interneuron-pyramidal cell pairs. $A$, Depression of IPSP amplitude is observed during conditioning by backpropagating action potential trains in pyramidal cell dendrites. B, VGLUT inhibition by EB abolishes this depression, inducing potentiation of IPSPs. C, Increased intracellular chloride concentration in conjunction with EB induces potentiation of IPSP amplitude during conditioning. D, Depression of IPSPs during conditioning can be eliminated by an intracellular chloride concentration that inhibits all known VGLUT isoforms (Bellocchio et al., 2000; Schäfer et al., 2002). Top plots in each panel show examples of recordings with differing intracellular solutions. The mean IPSP amplitude is represented by horizontal lines, and the corresponding IPSP records are shown on the top. Bottom plots, Each circle represents the mean amplitude from all experiments $(n=5$ in $A ; n=4$ in $B ; n=6$ in $C ; n=4$ in $D)$. In each experiment, the IPSP amplitudes were normalized to the average amplitude in control. Subsequently, at equal times during the experimental protocol, normalized IPSPs were averaged.

Varma et al., 2001) and an increase in dendritic $\mathrm{Ca}^{2+}$ concentration (Di Marzo et al., 1998).

Short-term regulation of transmitter release via retrograde signaling in FSN-pyramidal inhibitory synapses strongly depends on the activation of mGluRs and is triggered by an increase in dendritic $\mathrm{Ca}^{2+}$ concentration (Zilberter, 2000). The major finding of our present report is that retrograde signaling between FSN interneurons and pyramidal cells, despite pharmacological similarities with endocannabinoid signaling, is not mediated by endocannabinoids but by the novel mechanism of dendritic vesicular release of glutamate (Fig. 9). VGLUT-mediated glutamate transport into vesicles is suggested to play a role in retrograde signaling, because inhibition of VGLUT activity abolished retrograde signaling.

\section{Distribution of VGLUTs in neocortex}

VGLUT1, VGLUT2, and VGLUT3 function to shuttle glutamate into synaptic vesicles (for review, see Masson et al., 1999). All known VGLUT isoforms exhibit high sequence homology, selectivity for glutamate, and similar sensitivity to $\mathrm{EB}$ and $\mathrm{Cl}^{-}$ concentrations (Bellocchio et al., 2000; Schäfer et al., 2002). VGLUT1 and VGLUT2 are localized to mostly nonoverlapping populations of glutamatergic axon terminals throughout the CNS. Their cellular distribution therefore supports their suggested function in anterograde synaptic communication (Fremeau et al., 2001).

In contrast, VGLUT3 expression in neocortex is confined to a distinct subset of GABAergic interneurons, predominantly containing CCK and coexpressing $\mathrm{CB} 1$ receptors, and to the dendritic arbor and somata of pyramidal cells. These "noncanonical" sites of VGLUT3 localization, together with its presence in other types of non-glutamatergic neurons throughout the rodent forebrain (Gras et al., 2002; Schäfer et al., 2002; Harkany et al., 2003), suggest that VGLUT3 may be critical for as yet unknown signaling mechanisms. Although previous studies show unanimously that VGLUT3 is expressed by subsets of non-glutamatergic neurons in the neocortex, hippocampus, striatum, and raphe nuclei, the presence of VGLUT3 in principal cells of the neocortex and hippocampus remains rather controversial. Although Fremeau et al. (2002), using riboprobes, demonstrated the abundant presence of VGLUT3 mRNA transcripts in the neocortex, including cell groups with strong (putative interneurons) and weak (putative pyramidal cells) 
A

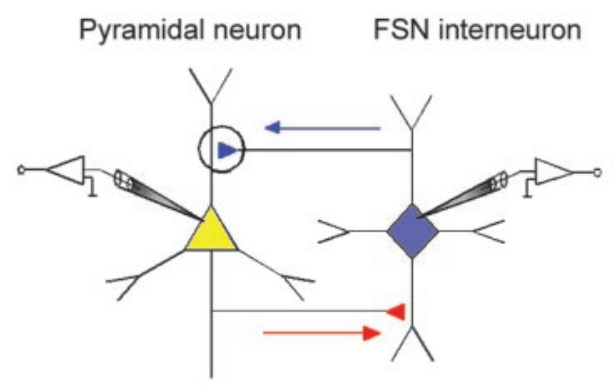

$\mathrm{B}$

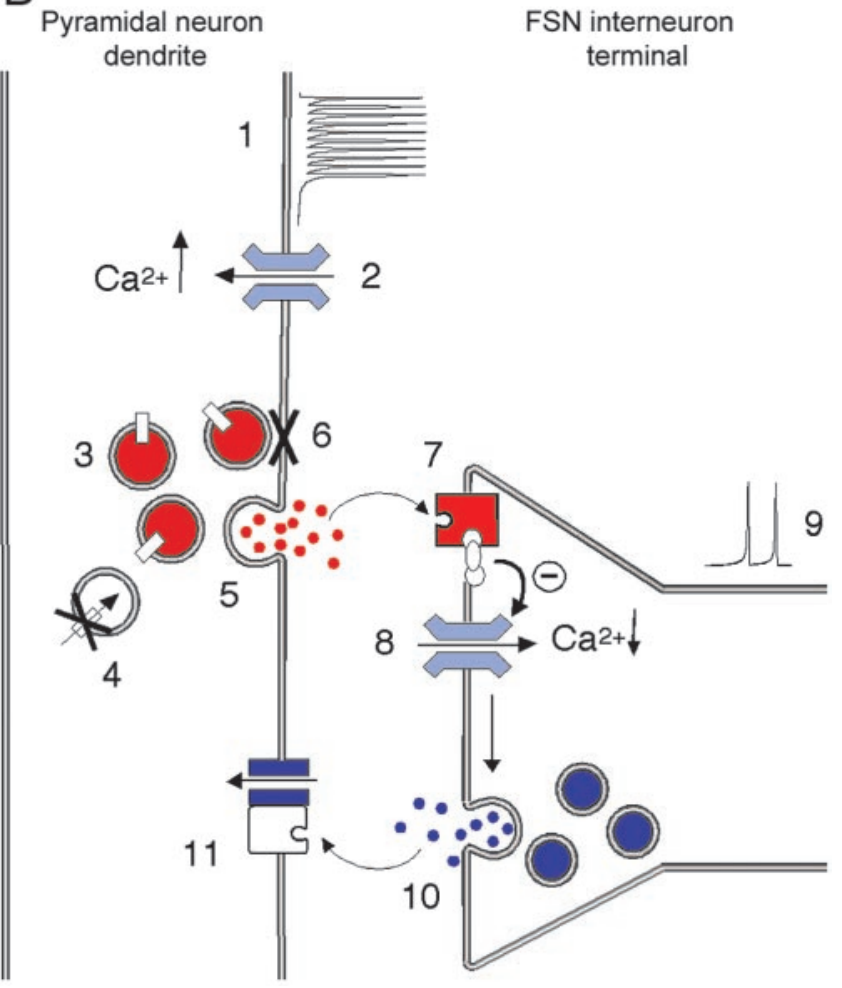

Figure 9. Regulation of the efficacy of inhibitory transmission by dendritic vesicular glutamate release. $A$, In a microcircuit of a reciprocally connected pyramidal cell and an FSN interneuron, axonal action potentials in the pyramidal cell excite the interneuron (red), whereas backpropagating dendritic action potentials (circle) reduce the inhibitory effect of the interneuron (blue) via the retrograde signaling pathway. $B$, Backpropagating action potentials in pyramidal cell dendrites (1) cause an increase in dendritic $\mathrm{Ca}^{2+}$ concentration (2), inducing exocytosis (5) of glutamate-containing vesicles (3). Uptake of glutamate into dendritic vesicles can be blocked by VGLUT inhibition using Evans blue or a high intracellular $\mathrm{Cl}^{-}$concentration (4). Vesicular exocytosis can be blocked by botulinum toxin D (Xu et al., 1998) or GDP- $\beta S$ (Hess et al., 1993) (6). Exocytosed glutamate activates metabotropic glutamate receptors in the axon terminal (Zilberter, 2000) (7), resulting in the inhibition of voltage-dependent $\mathrm{Ca}^{2+}$ channels (8). Consequently, a reduced $\mathrm{Ca}^{2+}$ influx induced by axonal action potentials in the FSN interneuron (9) results in a decrease of the release probability of GABA-containing synaptic vesicles (10). Finally, reduced activation of $\mathrm{GABA}_{A}$ receptors in the pyramidal cell dendrite leads to suppression of IPSPs (11).

hybridization signal, Gras et al. (2002) and Schäfer et al. (2002) did not report weak hybridization signals in the neocortex when using VGLUT3 oligonucleotide probes. Here, we substantiated the previous findings of Fremeau et al. (2002) using both targetspecific isolation combined with Western blotting and immunocytochemistry, and our findings corroborate the in situ hybridization data reported previously.

Previous data on the effect of exocytosis inhibitors, such as botulinum toxin D (Xu et al., 1998) and GDP- $\beta$ S (Hess et al.,
1993), on retrograde signaling (Zilberter et al., 1999; Zilberter, 2000) suggest exocytosis as the mechanism of vesicle release from dendrites. Electron microscopy analysis confirmed that VGLUT3 may be localized to vesicle-like structures that show a tendency to accumulate in close proximity to postsynaptic specializations in dendritic shafts of pyramidal cells. When released into the synaptic cleft, glutamate acts on presynaptic mGluRs localized on GABAergic terminals (Zilberter, 2000) that negatively couple to GABA release (Fig. 9). In this cascade, mGluRs serve as high-affinity presynaptic sensors of the retrograde messenger, glutamate.

\section{Action of VGLUT inhibitors}

Retrograde signaling was inhibited by application of EB in the postsynaptic pyramidal cell. EB is commonly used to monitor changes in blood volume and extravasation (Roseth et al., 1995). EB exhibits cytotoxicity on cultured neurons; however, this effect becomes significant only after prolonged EB exposure (Israel et al., 2001). EB was shown to block AMPA-kainate receptors at concentrations approximately two orders of magnitude higher $\left(\sim 10 \mu \mathrm{M} \mathrm{IC}_{50}\right)$ than that for VGLUT3 (Schurmann et al., 1997), whereas its modulatory action on GABA receptors was not reported. Importantly, EB is an $\sim 250$ times less potent inhibitor of VGAT than of VGLUTs (Roseth et al., 1995, 1998), indicating the specificity of EB-mediated VGLUT inhibition. In our study, EB, when present, was used throughout the experiment in both the control and conditioning train period. The effects of EB on synaptic transmission occurred only during the period of the conditioning train. IPSP potentiation during this period was observed with even low (500 nM) concentrations of EB in the pipette solution. We thus suggest that the EB effects that we observed were caused by the inhibition of VGLUT3, although we cannot rule out the possibility that the drug effects were caused by the inhibition of an as yet unidentified VGLUT isoform.

\section{Potentiation of IPSPs}

Inhibition of glutamate uptake by $\mathrm{EB}$ or $145 \mathrm{mM}\left[\mathrm{Cl}^{-}\right]_{\mathrm{i}}$ resulted in the potentiation of IPSPs during conditioning. Although the mechanism of IPSP potentiation remains unclear, augmentation of $\mathrm{GABA}_{\mathrm{A}}$ receptor-channel conductance during $\mathrm{Ca}^{2+}$ increase (Llano et al., 1991) in pyramidal cell dendrites may underlie this effect. If we suggest that an increase in dendritic $\mathrm{Ca}^{2+}$ concentration initiates both IPSP potentiation and retrograde signaling in parallel, then the effects that we measured reflect the balance of these two opposing mechanisms. Therefore, we would have to conclude that the real effect of glutamate release on synaptic efficacy is larger than that observed by direct recordings.

\section{Conclusions}

One of the main questions of this study was the origin of retrograde messenger(s) providing feedback control between FSN and pyramidal cells. The results of the present and previous (Zilberter, 2000) reports show that (1) retrograde signaling in FSNpyramidal cell synapses is not mediated by endocannabinoid release, (2) retrograde signaling strongly depends on postsynaptic $\left[\mathrm{Ca}^{2+}\right]$ and is prevented by antagonists of vesicular exocytosis, (3) VGLUT3 is located in vesicle-like structures in dendrites of pyramidal cells, and (4) antagonists of VGLUT-mediated glutamate uptake abolish retrograde signaling. These results suggest that glutamate is a retrograde messenger at inhibitory synapses in layer $2 / 3$ of neocortex.

Accumulation of glutamate in storage vesicles in pyramidal cell dendrites requires the presence of transporter, such as 
VGLUT3, for this negative feedback regulation of synaptic efficacy at synaptic contacts between FSN interneurons and pyramidal cells. The axonal, VGLUT1-, or VGLUT2-mediated and dendritic, VGLUT3-mediated, vesicular release machineries provide a dual role for glutamate in neuronal communication. Importantly, glutamate release from pyramidal cell dendrites follows the classic scenario of quantal exocytosis, suggesting that glutamate-mediated retrograde synaptic communication, in contrast to endocannabinoid signaling (Wilson and Nicoll, 2001), affects only particular synapses in a "targeted" manner. Recently, Trettel and Levine (2003) reported endocannabinoidmediated retrograde signaling at inhibitory synapses in layer $2 / 3$ pyramidal cells. These data together with our present findings therefore suggest that pyramidal cells may simultaneously use functionally different mechanisms of retrograde signaling to control the efficacy of input synapses of distinct origin along their dendritic arbor.

\section{References}

Alger BE (2002) Retrograde signaling in the regulation of synaptic transmission: focus on endocannabinoids. Prog Neurobiol 68:247-286.

Baude A, Nusser Z, Molnár E, McIlhinney RA, Somogyi P (1995) Highresolution immunogold localization of AMPA type glutamate receptor subunits at synaptic and non-synaptic sites in rat hippocampus. Neuroscience 69:1031-1055.

Bellocchio EE, Reimer RJ, Fremeau Jr RT, Edwards RH (2000) Uptake of glutamate into synaptic vesicles by an inorganic phosphate transporter. Science 289:957-960.

Buhl EH, Tamás G, Szilágyi T, Stricker C, Paulsen O, Somogyi P (1997) Effect, number and location of synapses made by single pyramidal cells onto aspiny interneurons of cat visual cortex. J Physiol (Lond) 500:689-713.

Chaudhry FA, Reimer RJ, Bellocchio EE, Danbolt NC, Osen KK, Edwards RH, Storm-Mathisen J (1998) The vesicular GABA transporter, VGAT, localizes to synaptic vesicles in sets of glycinergic as well as GABAergic neurons. J Neurosci 18:9733-9750.

Devane WA, Dysarz III FA, Johnson MR, Melvin LS, Howlett AC (1988) Determination and characterization of a cannabinoid receptor in rat brain. Mol Pharmacol 34:605-613.

Di Marzo V, Melck D, Bisogno T, De Petrocellis L (1998) Endocannabinoids: endogenous cannabinoid receptor ligands with neuromodulatory action. Trends Neurosci 21:521-528.

Fremeau Jr TR, Troyer MD, Pahner I, Nygaard GO, Tran CH, Reimer RJ, Bellocchio EE, Fortin D, Storm-Mathisen J, Edwards RH (2001) The expression of vesicular glutamate transporters defines two classes of excitatory synapse. Neuron 31:247-260.

Fremeau Jr RT, Burman J, Qureshi T, Tran CH, Proctor J, Johnson J, Zhang H, Sulzer D, Copenhagen DR, Storm-Mathisen J, Reimer RJ, Chaudhry FA, Edwards RH (2002) The identification of vesicular glutamate transporter 3 suggests novel modes of signaling by glutamate. Proc Natl Acad Sci USA 99:14488-14493.

Fremeau Jr RT, Voglmaier S, Seal RP, Edwards RH (2004) VGLUTs defines subsets of excitatory neurons and suggest novel roles for glutamate. Trends Neurosci 27:98-103.

Freund TF, Gulyas AI (1991) GABAergic interneurons containing calbindin D28K or somatostatin are major targets of GABAergic basal forebrain afferents in the rat neocortex. J Comp Neurol 314:187-199.

Fujiyama F, Furuta T, Kaneko T (2001) Immunocytochemical localization of candidates for vesicular glutamate transporters in the rat cerebral cortex. J Comp Neurol 435:379-387.

Gras C, Herzog E, Bellenchi GC, Bernard V, Ravassard P, Pohl M, Gasnier B, Giros B, El Mestikawy S (2002) A third vesicular glutamate transporter expressed by cholinergic and serotoninergic neurons. J Neurosci 22:5442-5451.

Harkany T, Härtig W, Berghuis P, Dobszay MB, Zilberter Y, Edwards RH, Mackie K, Ernfors P (2003) Complementary distribution of type 1 cannabinoid receptors and vesicular glutamate transporter 3 in basal forebrain suggests input-specific retrograde signaling by cholinergic neurons. Eur J Neurosci 18:1979-1992.

Herzog E, Gilchrist J, Gras C, Muzerelle A, Ravassard P, Giros B, Gaspar P, El
Mestikawy S (2004) Localization of VGLUT3, the vesicular glutamate transporter type 3, in the rat brain. Neuroscience 123:983-1002.

Hess SD, Doroshenko PA, Augustine GJ (1993) A functional role of GTPbinding proteins in synaptic vesicle cycling. Science 259:1169-1172.

Holmgren C, Harkany T, Svennenfors B, Zilberter Y (2003) Pyramidal cell communication within local networks in layer $2 / 3$ of rat neocortex. J Physiol (Lond) 551:139-153.

Israel M, Tomasi M, Bostel S, Meunier FM (2001) Cellular resistance to Evans Blue toxicity involves an up-regulation of a phosphate transporter implicated in vesicular glutamate storage. J Neurochem 78:658-663.

Kaneko T, Fujiyama F, Hioki H (2002) Immunohistochemical localization of candidates for vesicular glutamate transporters in the rat brain. J Comp Neurol 444:39-62.

Katona I, Sperlágh B, Sik A, Kafalvi A, Vizi ES, Mackie K, Freund TF (1999) Presynaptically located CB1 cannabinoid receptors regulate GABA release from axon terminals of specific hippocampal interneurons. J Neurosci 19:4544-4558.

Katona I, Rancz EA, Acsády L, Ledent C, Mackie K, Hajos N, Freund TF (2001) Distribution of CB1 cannabinoid receptors in the amygdala and their role in the control of GABAergic transmission. J Neurosci 21:9506-9518.

Kettunen P, Hallén K, El Manira A (2002) Release of endogenous cannabinoids by group I mGluR activation modulates the locomotor rhythm in the lamprey. Soc Neurosci Abstr 28:167.

Kreitzer AC, Regehr WG (2001a) Retrograde inhibition of presynaptic calcium influx by endogenous cannabinoids at excitatory synapses onto Purkinje cells. Neuron 29:717-727.

Kreitzer AC, Regehr WG (2001b) Cerebellar depolarization-induced suppression of inhibition is mediated by endogenous cannabinoids. J Neurosci 21:RC174(1-5).

Li JL, Fujiyama F, Kaneko T, Mizuno N (2003) Expression of vesicular glutamate transporters, VGluT1 and VGluT2, in axon terminals of nociceptive primary afferent fibers in the superficial layers of the medullary and spinal dorsal horns of the rat. J Comp Neurol 457:236-249.

Llano I, Leresche N, Marty A (1991) Calcium entry increases the sensitivity of cerebellar Purkinje cells to applied GABA and decreases inhibitory synaptic currents. Neuron 6:565-574.

Ludwig M, Pittman QJ (2003) Talking back: dendritic neurotransmitter release. Trends Neurosci 26:255-261.

Maejima T, Hashimoto K, Yoshida T, Aiba A, Kano M (2001) Presynaptic inhibition caused by retrograde signal from metabotropic glutamate to cannabinoid receptors. Neuron 31:463-475.

Markram H, Lübke J, Frotscher M, Roth A, Sakmann B (1997) Physiology and anatomy of synaptic connections between thick tufted pyramidal neurones in the developing rat neocortex. J Physiol (Lond) 500:409-440.

Markram H, Wang Y, Tsodyks M (1998) Differential signaling via the same axon of neocortical pyramidal neurons. Proc Natl Acad Sci USA 95:5323-5328.

Masson J, Sagne C, Hamon M, El Mestikawy S (1999) Neurotransmitter transporters in the central nervous system. Pharmacol Rev 51:439-464.

Pike CJ, Burdick D, Walencewicz AJ, Glabe CG, Cotman CW (1993) Neurodegeneration induced by $\beta$-amyloid peptides in vitro: the role of peptide assembly state. J Neurosci 13:1676-1687.

Pitler TA, Alger BE (1992) Postsynaptic spike firing reduces synaptic $\mathrm{GABA}_{\mathrm{A}}$ responses in hippocampal pyramidal cells. J Neurosci $12: 4122-4132$

Preuss TM, Stepniewska I, Jain N, Kaas JH (1997) Multiple divisions of macaque precentral motor cortex identified with neurofilament antibody SMI-32. Brain Res 767:148-153.

Reyes A, Lujan R, Rozov A, Burnashev N, Somogyi P, Sakmann B (1998) Target-cell-specific facilitation and depression in neocortical circuits. Nat Neurosci 1:279-285.

Roseth S, Fykse EM, Fonnum F (1995) Uptake of L-glutamate into rat brain synaptic vesicles: effect of inhibitors that bind specifically to the glutamate transporter. J Neurochem 65:96-103.

Roseth S, Fykse EM, Fonnum F (1998) Uptake of L-glutamate into synaptic vesicles: competitive inhibition by dyes with biphenyl and amino- and sulphonic acid-substituted naphthyl groups. Biochem Pharmacol 56:1243-1249.

Rozov A, Jerecic J, Sakmann B, Burnashev N (2001) AMPA receptor channels with long-lasting desensitization in bipolar interneurons contribute 
to synaptic depression in a novel feedback circuit in layer $2 / 3$ of rat neocortex. J Neurosci 21:8062-8071.

Schäfer MK, Varoqui H, Defamie N, Weihe E, Erickson JD (2002) Molecular cloning and functional identification of mouse vesicular glutamate transporter 3 and its expression in subsets of novel excitatory neurons. J Biol Chem 277:50734-50748.

Schnell SA, Staines WA, Wessendorf MW (1999) Reduction of lipofuscinlike autofluorescence in fluorescently labeled tissue. J Histochem Cytochem 47:719-730.

Schurmann B, Wu X, Dietzel ID, Lessmann V (1997) Differential modulation of AMPA receptor mediated currents by Evans Blue in postnatal rat hippocampal neurones. Br J Pharmacol 121:237-247.

Sjöström PJ, Turrigiano GG, Nelson SB (2003) Neocortical LTD via coincident activation of presynaptic NMDA and cannabinoid receptors. Neuron 39:641-654.

Takamori S, Rhee JS, Rosenmund C, Jahn R (2000a) Identification of a vesicular glutamate transporter that defines a glutamatergic phenotype in neurons. Nature 407:189-194.

Takamori S, Riedel D, Jahn R (2000b) Immuno-isolation of GABA-specific synaptic vesicles defines a functionally distinct subset of synaptic vesicles. J Neurosci 20:4904-4911.

Takamori S, Rhee JS, Rosenmund C, Jahn R (2001) Identification of differentiation-associated brain-specific phosphate transporter as a second vesicular glutamate transporter (VGLUT2). J Neurosci 21:RC182(1-4).

Takamori S, Malherbe P, Broger C, Jahn R (2002) Molecular cloning and functional characterization of human vesicular glutamate transporter 3 . EMBO J 3:798-803.

Trettel J, Levine ES (2003) Endocannabinoids mediate rapid retrograde signaling at interneuron-pyramidal neuron synapses of the neocortex. J Neurophysiol 89:2334-2338.

Tsou K, Brown S, Sanudo-Pena MC, Mackie K, Walker JM (1998) Immunohistochemical distribution of cannabinoid CB1 receptors in the rat central nervous system. Neuroscience 83:393-411.

Varma N, Carlson GC, Ledent C, Alger BE (2001) Metabotropic glutamate receptors drive the endocannabinoid system in hippocampus. J Neurosci 21:RC188(1-5).

Wang Y, Gupta A, Toledo-Rodriguez M, Wu CZ, Markram H (2002) Anatomical, physiological, molecular and circuit properties of nest basket cells in the developing somatosensory cortex. Cereb Cortex 12:395-410.

Wilson RI, Nicoll RA (2001) Endogenous cannabinoids mediate retrograde signaling at hippocampal slices. Nature 410:588-592.

Xu T, Bin T, Niemann H, Neher E (1998) Multiple kinetic components of exocytosis distinguished by neurotoxin sensitivity. Nat Neurosci 1:192-200.

ZilberterY (2000) Dendritic release of glutamate suppresses synaptic inhibition of pyramidal neurons in rat neocortex. J Physiol (Lond) 528:489-496.

Zilberter Y, Kaiser KMM, Sakmann B (1999) Dendritic GABA release depresses excitatory transmission between L $2 / 3$ pyramidal and bitufted neurons in rat neocortex. Neuron 24:979-988. 